\title{
Molecular identification of Nematodirus spathiger (Nematoda: Molineidae) in Lama guanicoe from Patagonia, Argentina
}

\author{
R. S. PETRIGH, M. H. FUGASSA
}

CONICET-Lab. Paleoparasitología, Depto. de Biología, Facultad de Ciencias Exactas y Naturales, Universidad Nacional de Mar del Plata, Dean Funes 3350, Mar del Plata (7600), Buenos Aires, Argentina,

E-mail: rpetrigh@gmail.com

\begin{abstract}
Summary
The guanaco (Lama guanicoe) is the major inhabitant and the largest wild artiodactyl in Patagonia. The introduction of invasive species into its ecological niche poses ecological risks, since invasive species may introduce harmful parasites to this native species. In this work, filariform larvae of the Nematodirus genus were found in feces of guanacos from the Perito Moreno National Park in Argentina. All species were characterized according to morphological features and molecular analyses using ribosomal DNA (rDNA). For the molecular analysis, rDNA fragments were amplified by PCR and then sequenced. The results of the BLASTN comparison threw a $99 \%$ of identity with Nematodirus spathiger and $97 \%$ with $N$. helvetianus, suggesting that $N$. spathiger is the infecting parasite. Nematodirus spathiger together with $N$. filicollis and $N$. battus causes diarrhea and deaths in sheep and, in some cases, in South American camelids. The availability of more accurate diagnostic methods such as PCR could improve the control measures for gastrointestinal helminthiasis.
\end{abstract}

Keywords: filariform larvae; coproparasitology; PCR; ribosomal DNA (rDNA)

\section{Introduction}

The guanaco (Lama guanicoe) is the major artiodactyl that inhabits in Patagonia. Until the Pleistocene-Holocene Transition, other large artiodactyls inhabited Patagonia along with the guanaco. At least five archaeological sites from Southern Patagonia show an association between L. guanicoe and L. gracilis (extinct species) (Cajal et al., 2010). The guanaco population extends from Peru at $8{ }^{\circ} \mathrm{S}$ to the Isla Navarino (archipelago of Tierra del Fuego, Chile) at $55^{\circ} \mathrm{S}$ (Wheeler, 1995). Nowadays, guanacos occupy a $40 \%$ of the original area that they inhabited at pre-Hispanic times (Franklin et al., 1997), with about
840,000 individuals in all (González et al., 2006), from which 400,000 inhabit in Patagonia (Amaya et al., 2001). Parasites act as density-dependent factors regulating host population sizes (Anderson \& May, 1979), particularly the wild species population (Tompkins \& Begon, 1999). Wild animals are susceptible to pressures from human activity (direct or indirect). For instance, the invasive species, which are product of human activity, that are placed into the guanaco ecological habitat may introduce harmful parasites to this, and others, native species (Prenter et al., 2004). These invasive species, therefore, may cause a high impact in wildlife (Scott, 1988).

A wide range of parasites have been reported for L. guanicoe from Patagonia by coproparasitological studies, necropsy examinations or through gastrointestinal lavages. Nematodes of the Trichostrongyloidea Superfamily are the gastrointestinal helminthes most frequently reported in guanacos: Cooperia (Larrieu et al., 1982; Navone \& Merino, 1989), Trichostrongylus (Larrieu et al., 1982; Navone \& Merino, 1989; Karesh et al. 1998; among others), Marshallagia (Navone \& Merino, 1989; Karesh et al., 1998; Beldomenico et al., 2003), Haemonchus (Navone \& Merino, 1989), Nematodirus (Larrieu et al., 1982; Navone \& Merino, 1989; Beldomenico et al., 2003; Correa et al., 2012; among others) and Ostertagia (Navone \& Merino, 1989). Nematodirus battus, $N$. filicollis, $N$. spathiger and N. lanceolatus, within the Nematodirus sp., have been reported through gastrointestinal lavage inspection (Larrieu et al., 1982).

The life cycle of the Trichostrongyloids parasites involves a rhabditiform larva (L1), which moults and matures in the infective filariform larva (L3). These stages are found in the pasture and the infective form, L3, enters in the susceptible host during its feeding, closing the cycle when it matures in the host intestine (Anderson, 2000). Hence, these parasites represent a risk to wild artiodactyls because of their eating habits (Leguía \& Casas, 1999). 
The specific diagnostic is important to study the transmission patterns of specific parasites in order to evaluate the introduction and movement of gastrointestinal helminthes of wild and domestic invasive species. The aim of this work was to identify the genus and species of larvae isolated in coproparasitological samples of wild guanacos from Patagonia. The analysis of genus and species was performed through molecular tools of DNA purification and PCR amplification of ribosomal DNA fragments (rDNA).

\section{Materials and methods}

The feces of guanacos were collected in the Río Robles valley in the Perito Moreno National Park, Santa Cruz province, Argentina. The samples were taken by members of the National Park Board of Management during the month of May (2011). Groups of 3 to 8 dry pellets were rehydrated with $0.5 \%$ aqueous trisodium phosphate (Callen and Cameron, 1960). Then, the pellets were crushed and disintegrated with $0.2 \% \mathrm{v} / \mathrm{v}$ tween 20 by vortex for $1 \mathrm{~min}$. The processed pellets were sieved using $290 \mu \mathrm{m}$ nylon mesh and they were allowed to settle for $3 \mathrm{~h}$ when sediment was formed. This recovered pellet was kept in $70 \% \mathrm{v} / \mathrm{v}$ Ethanol at $4{ }^{\circ} \mathrm{C}$.

Microscopic examinations for parasite identification were performed under a light microscope (100x magnification). A total of $30 \mu \mathrm{l}$ of sediment were mixed with a glycerin drop to avoid desiccation of the preparation and this mix was then placed on slides. No coverslips were used. Larvae were manually isolated with a capillary tube that acts as a Pasteur pipette and then they were washed by subsequent transfers of a drop of sterile phosphate buffered saline (PBS) $1 \mathrm{X}$ on the slide. The larvae were continuously kept in $2 \mu$ of sterile PBS $1 \mathrm{X}$.

The DNA extraction was performed by lysis-PCR method (Gasser et al., 1993) with modifications. Briefly, a final volume of $25 \mu \mathrm{l}$ containing fragments of larvae was agitated by vortex during $1 \mathrm{~min}$ in compatible lysis-PCR buffer $(50 \mathrm{mM} \mathrm{KCl}, 10 \mathrm{mM}$ Tris- $\mathrm{HCl} \mathrm{pH} 8.8,0.4 \% \mathrm{v} / \mathrm{v}$ Nonidet P-40, $0.8 \% \mathrm{v} / \mathrm{v}$ Tween $20,2.5 \mathrm{mM} \mathrm{MgCl} 2$ ) with a subsequent ice incubation for $10 \mathrm{~min}$. Then, the samples were digested with $400 \mu \mathrm{g} / \mathrm{ml}$ of proteinase $\mathrm{K}$ (Biobasic) for $2 \mathrm{~h}$ at $56^{\circ} \mathrm{C}$ and over night at $37^{\circ} \mathrm{C}$. Finally, the processed samples were boiled for $15 \mathrm{~min}$ to inactivate the proteinase $\mathrm{K}$ and $50 \mu \mathrm{l}$ of sterile ultrapure water were added. After centrifugation at 2,000 X $\mathrm{g}$ for $5 \mathrm{~min}$, the supernatant was kept at $-20{ }^{\circ} \mathrm{C}$ for subsequent use in PCR. A negative control of DNA extraction was included.

For the molecular identification of larvae, the rDNA fragment including the $18 \mathrm{~S} 3$ 'end, ITS-1, ITS-2, the $5.8 \mathrm{~S}$ subunit or the $28 \mathrm{~S} 5$ ' end was amplified by PCR using the primers NC5 (forward) and NC2 (reverse) (Gasser et al., 1996). PCR amplifications were performed by triplicates with $2 \mu \mathrm{l}$ of DNA in a final volume of $25 \mu \mathrm{l}$. The amplifications were made using 0.65 units of Taq DNA Polymerase (Fermentas) in 10X Taq DNA polymerase buffer (Fermentas), $2 \mathrm{mM}$ of $\mathrm{MgCl}_{2}$ (Fermentas), $200 \mu \mathrm{M}$ of each dNTP (Finnzymes) and $0.4 \mathrm{mM}$ of each primer. PCR con- ditions were as follows: an initial denaturing step at $94{ }^{\circ} \mathrm{C}$ for $3 \mathrm{~min}$, followed by 40 cycles at $94{ }^{\circ} \mathrm{C}$ for $1 \mathrm{~min}, 55^{\circ} \mathrm{C}$ for $1 \mathrm{~min}$, and $72{ }^{\circ} \mathrm{C}$ for $1 \mathrm{~min}$, and a final extension step at $72{ }^{\circ} \mathrm{C}$ for $10 \mathrm{~min}$. Negative PCR controls were added. Triplicates of the specific fragment were sequenced and the obtained sequences and chromatograms were analyzed using the BioEdit v7.2.0 program. The obtained consensus sequences were compared with the GenBank sequences by using the BLASTN algorithm (http://blast.ncbi.nlm.nih. gov/Blast.cgi) of the National Center for Biotechnology Information (NCBI).

\section{Results and discussion}

The optical microscopy observation allowed us to identify nematode infective filariform larvae with a shell, which probably belongs to the Nematodirus genus (Molineidae Family) (Fig. 1) because of the tail length and the shape of its anterior region (Niec, 1968; van Wyk \& Mayhew, 2013). Three 849 bp identical sequences corresponding to rDNA fragments amplified by PCR were obtained from the three analyzed larvae. The BLASTN analysis of each consensus sequence with nonredundant nucleotide sequences from the NCBI databases showed a $99 \%$ of identity with other Nematodirus spathiger sequences (AF194144.1, AF194143.1 and AF194128.1) and $97 \%$ of identity with $N$. helvetianus sequences (AF194127.1, AF194142.1, AF194141.1 and JQ828846.1). Both species are very similar genetically, showing differences of $3.9 \%$ between the ITS-2 nucleotide sequences (Newton et al., 1998). Our results are in line with previous findings in the literature (Newton et al., 1998). Therefore, the larvae found from guanaco feces in the present research were identified as $N$. spathiger and the sequences were submitted in the GenBank (KF305647.1).

Generally, the Nematodirus sp. parasites have been identified by methods based on morphological characters of adult males such as the spicule tips, copulatory bursae and the distribution of bosses on the inside surface of the copulatory bursa (Becklund \& Walker, 1967). Lichtenfels and Pilitt (1983) created a key to distinguish between females and males of the different species of the Nematodirus genus according to cuticular ridge patterns. However, the identification of Nematodirus species based on morphological characters is difficult when immature parasite remains from feces are studied. Therefore, the culture of larvae from fresh feces is useful to obtain filariform larvae for diagnosis, but unfortunately the culture frequently fails.

The identification of parasites is facilitated by molecular techniques since they provide useful tools for taxonomic classification of a wide range of parasites. In this regard, the rDNA has been used as a genetic marker for the differentiation between genera, including species of different taxa (Holterman et al., 2006; Carreno et al., 2012). For instance, $N$. spathiger, $N$. helvetianus, N. filicollis and $N$. battus have been identified through the PCR amplification and sequencing of the internal transcribed spacer (ITS)-2 (Newton et al., 1998). In addition, PCR amplification and 


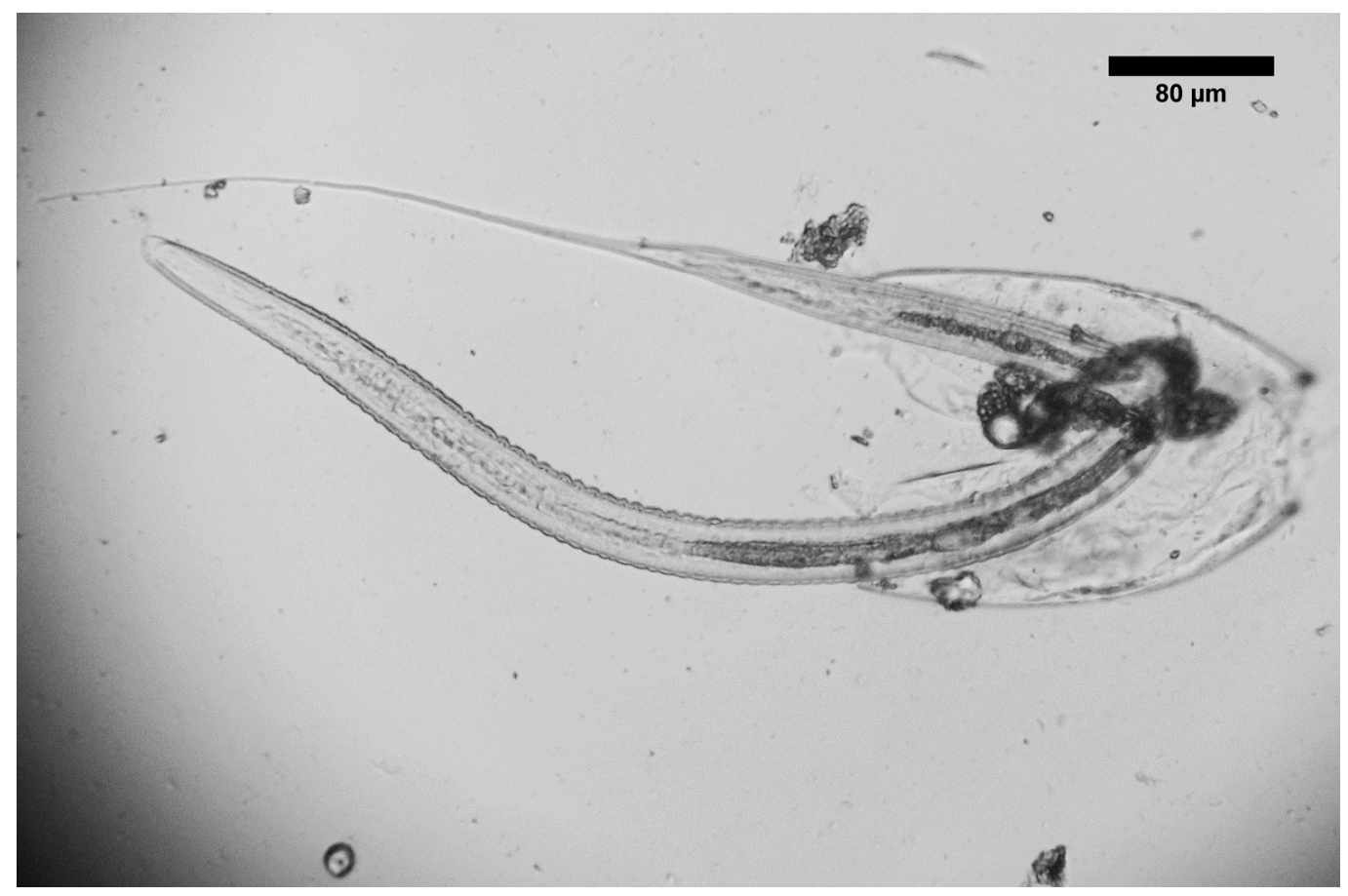

Fig. 1. Nematodirus filariform Larvae L3 found by light microscopy. A - 400x. Scale Bar $=80 \mu \mathrm{m}$.

sequencing of rDNA regions containing the $3^{\prime}$ end of the $18 \mathrm{~S}$ gene, ITS-1, ITS-2, the $5.8 \mathrm{~S}$ subunit and the $5^{\prime}$ end of the $28 \mathrm{~S}$ gene have been widely used in Nematodirus sp. identification (Nadler et al., 2000). This rDNA fragments have been used in specific diagnosis of Trichostrongyloidea parasites found in wild and domestic ruminants (Gasser et al., 1999; Nadler et al., 2000).

In the present research, we demonstrated that the rDNA amplification is useful for the specific diagnosis of filariform larvae previously identified as Nematodirus sp. by optic microscopy.

The effects of Nematodirus spp. on the host vary according to the intensity of the infection. For instance, $N$. spathiger with $N$. filicollis and $N$. battus cause diarrhea and deaths in sheep and, in some cases, in South-American camelids (Leguía \& Casas, 1999; Marquardt et al., 1959). Nematodirus spp. larva hatching is associated with the possibility of feces to disintegrate so that the eggs that are captured within them can be released (Gibson \& Everett, 1981). The rain is important factor for disintegration of feces but it does not increase egg hatching or filariform larvae migration. Studies done in USA in similar latitudes of Perito Moreno National Park showed survivability through the time indicating that direct sunlight and high temperature of soil are the most limiting factors (Marquardt et al., 1959). Therefore, these parasites are highly resistant to adverse conditions in the environment.

The infection of $N$. spathiger parasites of guanacos from Perito Moreno National Park could be explained by the invasion by sheep of the ecosystem wherein the guanaco inhabits and the effect of resistant infective forms in the environment. These findings warn about the difficulty in the control of parasitism derived from invasive species as sheep within a protected area and particularly in species with high mobility as the guanaco. The availability of more specific identification methods such as PCR together with the morphological analysis could help in improving the diagnosis to these parasitic diseases. Besides, the knowledge of these parasitic species would allow the design of strategies for the prevention and control of disease outbreaks, which will contribute to the conservation of wildlife.

\section{Acknowledgment}

We thank park rangers from the Perito Moreno National Park and Lic. Nadia Velazquez for providing the samples studied in this research. We also thank to Dra. Julia Sabio y García for English editing. This study was supported by Consejo Nacional de Investigaciones Científicas y Tecnológicas (CONICET), Argentina (PIP 090), FONCyT (PICT 2316), and Universidad Nacional de Mar del Plata (UNMDP), Argentina (EXA 590).

\section{References}

ANDERSON, R. C. (2000): Nematode Parasites of Vertebrates: Their Development and Transmission, 2nd ed. CAB Publishing, London, England.

Anderson, R. M., MAY, R. M. (1979): Population Biology of Infectious Diseases: Part I. Nature, 280: $361-367$. DOI: $10.1038 / 280361 \mathrm{a} 0$

Amaya, J. N., Von Thüngen, J., De LAmo, D. A, (2001): Informe preliminar: Relevamiento y distribución de guanacos en la Patagonia. Comunicación técnica INTA Bariloche, 107: 1 - 12. Retrieved July 5, 2013 from http://bariloche.inta.gov.ar/?page_id $=688$

BeCKLund, W. W., WalKer, M. L. (1967): Nematodirus of domestic sheep, Ovis aries, in the United States with a 
key to the species. J. Parasitol., 5: 777 - 781. DOI: $10.2307 / 3276769$

Beldomenico, P. M., Uhart, M., Bono, M. F., Marull, C., BALDI, R., PERALTA, J. L. (2003): Internal parasites of free-ranging guanacos from Patagonia. Vet. Parasitol. 118(1 - 2): 71 - 77. DOI: 10.1016/j.bbr.2011.03.031 CAJAL, J., TONNI, E. P., TARTARINI, V. (2010): The extinction of some south american camelids: the case of Lama (vicugna) gracilis. Mastozool. Neotrop. 17(1):129 - 134

Callen, E. O., Cameron, T. W. M. (1960): A prehistoric diet revealed in coprolites. New Sci. 8: 35 - 40. DOI: 10.1590/S0036-46651998000600006

Carreno, R. A, Beade, M. S., Marull, C. A., Uhart, M. M., NADLER, S. A. (2012). Discovery of an undescribed protostrongylid nematode from the endangered pampas deer (Ozotoceros bezoarticus celer) in Argentina. J. Wildl. Dis., 48(3): 724 - 731. DOI: 10.7589/0090-3558-48.3.724 Correa, L., ZapatA, B., Soto-GamboA, M. (2012): Gastrointestinal and blood parasite determination in the guanaco (Lama guanicoe) under semi-captivity conditions. Trop. Anim. Health. Pro., 44(1): 11 - 15. DOI: 10.1007/s11250-011-9891-4

Franklin, W. L., BAS, F., BonaCiC, C. F., CunAzZA, C., Soto, N. (1997): Striving to manage Patagonia guanacos for sustained use in the grazing agroecosystems of southern Chile. Wild. Soc. Bull., 25: 65 - 73. DOI: $10.2307 / 3783283$

Gasser, R. B., Chilton, N. B, Hoste, H., Beveridge, I. (1993): Rapid sequencing of rDNA from single worms and eggs of parasitic helminths. Nucl. Acids. Res., 21: $2525-$ 2526. DOI: $10.1093 / \mathrm{nar} / 21.10 .2525$

Gasser, R. B., LeGoff, L., Petit, G., Bain, O. (1996): Rapid delineation of closely-related filarial parasites using genetic markers in spacer rDNA. Acta Trop., 62(3): $143-$ 150. DOI: 10.1016/S0001-706X(96)00035-6

GASSER, R. B., Rossi, L., ZHUA, X. (1999): Identification of Nematodirus species (Nematoda: Molineidae) from wild ruminants in Italy using ribosomal DNA marker. Int. J. Parasitol., 29: 1809 - 1817. DOI: 10.1016/S00207519(99)00123-X

Gibson, T. E., EvERETT, G. (1981): The ecology of the free living stages of Nematodirus battus. Res. Vet. Sci., 31: 323 $-327$

GonzÁlez, B. A., PAlma, R. E., Zapata, B., Marín, J. C. (2006): Taxonomic and biogeographical status of guanaco Lama guanicoe (Artiodactyla, Camelidae). Mammal. Rev. 36(2): 157 - 178. DOI: 10.4067/S0716-078X20070002 00001

Holterman, M., VAN DER WuRfF, A., VAN DEN Elsen, S., VAN MEgen, H., BONGERS, T., HOlOVACHOV, O., BAKKER, J., HELDER, J. (2006): Phylum-wide analysis of SSU rDNA reveals deep phylogenetic relationships among nematodes and accelerated evolution toward crown Clades. Mol. Biol. Evol. 23(9): 1792 - 1800. DOI: 10.1093/molbev/ms1044 Karesh, W. B., Uhart, M. M., Dierenfeld, E. S., BrA-

RECEIVED NOVEMBER 15, 2013
Selton, W. E., Torres, A., C House, C., Puche, H., CoOK, R. A. (1998): Health evaluation of free ranging guanaco (Lama guanicoe). J. Wildlife Dis., 29: 134 - 141. DOI: $10.2307 / 20095735$

LARrieu, E. J., Bigatti, R. O., Lukovich, R., EdDi, C., Bonazzi, E., Gómez, E., Niec, R., Oporto, N. (1982): Contribución al estudio del parasitismo gastrointestinal en guanacos (Lama guanicoe) y llamas (Lama glama). Gac. Vet. (Argentina), 44: 958 - 960

LEGUíA, P. G, CASAS, E. (1999): Enfermedades parasitarias de camélidos sudamericanos. Ed. de Mar, Lima, Perú Marquardt, W. C., Fritts, D. H., Senger, C. M., SEghetTi, L. (1959). The effect of weather on the development and survival of the free-living stages of Nematodirus spathiger (Nematoda: Trichostrongylidae). J. Parasitol., 45(4): 431 - 439. DOI: 10.2307/3274395

Lichtenfels, J. R., PilitT, P. A. (1983): Cuticular ridge patterns of Nematodirus (Nematoda: Trichostrongyloidea) parasitic in domestic ruminants of North America, with a key to species. Proc. Helminthol. Soc. Wash., 50(2):261 274. DOI: $10.1007 / \mathrm{BF} 00009161$

Nadler, S. A., Hoberg, E. P., Hudspeth, D. S. S., RICKARD, L. G., (2000). Relationships of Nematodirus species and Nemarodirus battus isolates (Nematoda: Trichostrongyloidea) based on nuclear ribosomal DNA sequences. J. Parasitol., 86(3): 588 - 601. DOI: 10.1645/00223395(2000)086[0588:RONSAN]2.0.CO;2

NIEC, R. (1968): Cultivo e identificación de larvas infectantes de nematodes gastrointestinales del bovino $y$ ovino. Manual Técnico No3, INTA.

NAvone, G., Merino, M. (1989). Contribución al conocimiento de la fauna endoparasitaria de Lama guanicoe, Muller, 1776, de Península Mitre, Tierra del Fuego, Argentina. Bol. Chil. Parasitol., 44: 46-51. Newton, L. A., Chilton, N. B., Beveridge, I., Gasser, R. B. (1998): Differences in the second internal transcribed spacer of four species of Nematodirus (Nematoda: Molineidae). Int. J. Parasitol., 28(2):337 - 341. DOI: 10.1016/S00207519(97)00150-1

Prenter, J., Macneil, C., Dick, J. T., DunN, A. M. (2004): Roles of parasites in animal invasions. Trends Ecol. Evol., 19(7): 385 - 390. DOI: 10.1016/j.tree.2004.05.002

ScOTT, M. E. (1988): The impact of infection and disease on animal populations: implications for conservation biology. Conserv. Biol., 2(1): 40 - 56. DOI: 10.1111/j.15231739.1988.tb00334.x

Tompkins, D. M., BEGON, M. (1999): Parasites can regulate wildlife populations. Parasitol. Today, 15: $311-313$. DOI: 10.1016/S0169-4758(99)01484-2

VAN WYK, J. A., MAYHEW, E. (2013): Morphological identification of parasitic nematode infective larvae of small ruminants and cattle: A practical lab guide. Onderstepoort $J$. Vet. Res., 80(1): 1 - 14. DOI: 10.4102/ojvr.v80i1.539 WHEELER, J. C. (1995): Evolution and present situation of the South American camelidae. Biol. J. Linn. Soc., 54: 271 - 295. DOI: 10.1016/0024-4066(95)90021-7

ACCEPTED APRIL 4, 2014 